\title{
Peroxisome proliferator-activated receptor $\delta$ and gastric cancer (Review)
}

\author{
CHUNG W. WU, JUN YU and JOSEPH J.Y. SUNG \\ Department of Medicine and Therapeutics, Prince of Wales Hospital, Institute of Digestive Disease, \\ The Chinese University of Hong Kong, Shatin, NT, Hong Kong, P.R. China
}

Received March 4, 2009; Accepted April 3, 2009

DOI: $10.3892 /$ or_00000456

\begin{abstract}
Peroxisome proliferator-activated receptors (PPARs) are members of the nuclear hormone receptor superfamily which form heterodimers with retinoid $X$ receptors (RXRs) in nucleus and bind to the PPAR response elements (PPREs) of target genes, leading to a wide spectrum of physiological functions. With an improved understanding of its physiological role, PPAR $\delta$ and its agonist have been gaining attention in cancer research in recent years. Despite the paucity of research concerning the direct relationship between PPAR $\delta$ and gastric cancer, there is substantial evidence that PPAR $\delta$ may play a role in the development of gastric cancer. This review focuses on recent literature describing the role of PPAR $\delta$, especially in its association with nuclear factor- $\mathrm{B}(\mathrm{NF}-\kappa \mathrm{B})$, interleukin-1ß (IL-1ß), cyclooxygenase-2 (COX-2) and Wnt- $\beta$-catenin/TCF-4 pathways on gastric tumorigenesis and highlights critical discrepancies that need to be resolved for a more comprehensive understanding of how this receptor modulates gastric tumorigenesis. The potential role of PPAR $\delta$ as a therapeutic target in the treatment of gastric cancer deserves further research focus.
\end{abstract}

\section{Contents}

1. Introduction

2. PPARs

3. PPAR $\delta$ and its ligands

4. Roles of PPAR $\delta$ in tumorigenesis

5. Background of gastric cancer

6. Potential effects of PPAR $\delta$ in gastric cancer

7. Conclusions

Correspondence to: Professor Joseph J.Y. Sung, Department of Medicine and Therapeutics, Prince of Wales Hospital, Institute of Digestive Disease, The Chinese University of Hong Kong, Shatin, NT, Hong Kong, P.R. China

E-mail: joesung@cuhk.edu.hk

Key words: gastric cancer, PPARd, NF-кB, IL-1ß, COX-2, Wnt pathway

\section{Introduction}

Gastric cancer is the second leading cause of cancer-related death in the world $(1,2)$ and the progress against it has been slow. Early stage gastric cancer is asymptomic, and at the time when gastric cancer demonstrates specific symptoms, it has usually proceeded to an advanced stage which subsequent therapy may have little impact (3). Screening for gastric cancer is still not commonly practiced in most countries and currently there is no promising adjuvant therapy. The need to explore novel therapeutics and chemopreventive agents is obvious.

The success of PPAR $\alpha$ and PPAR $\gamma$ as therapeutic targets has led to growing interests in PPARS. In recent years, the role of PPARS in cancer has attracted considerable research focus, especially in the formation of intestinal polyps and colon cancer. But still its role in gastric cancer has not been described. Nonetheless, PPARס demonstrates strong association with multiple pathways leading to gastric cancer. This review details the relationships between PPAR $\delta$ and nuclear factor- $\kappa \mathrm{B}(\mathrm{NF}-\kappa \mathrm{B})$, interleukin-1ß (IL-1B), cyclooxygenase-2 $(\mathrm{COX}-2)$ and the Wnt- 3 -catenin/TCF-4 pathways respectively, which are summarized in Fig. 1.

\section{PPARs}

Peroxisome proliferator activated receptors (PPARs) are members of the nuclear hormone receptor superfamily. PPARs form heterodimers with retinoid $X$ receptors (RXRs) in nucleus and bind to the PPAR response elements (PPREs) of target genes. PPREs are DNA sites composed of direct repeats of two core recognition motifs. In the absence of ligands, co-repressors bind to PPARs and induce condensation of chromatin and sequestration of promoter region, inhibiting transcriptional activity. In the presence of PPAR ligands, ligand-binding replaces the co-repressors from PPARs and triggers conformational changes of the heterodimer that facilitates the recruitment of transcriptional co-activators. Natural endogenous ligands of PPARs are mostly lipophilic molecules generated from fat and cellular metabolism with relatively low binding affinity. PPARs respond to them as lipid sensors by regulating gene transcription. However, function of PPARs is not only restricted to fat metabolism but also involved in a variety of physiological processes (4).

PPAR $\alpha, \gamma$ and $\delta / \beta$ are the three PPAR isotypes in mammals. PPAR $\alpha$ was the first to be identified when it demonstrated 


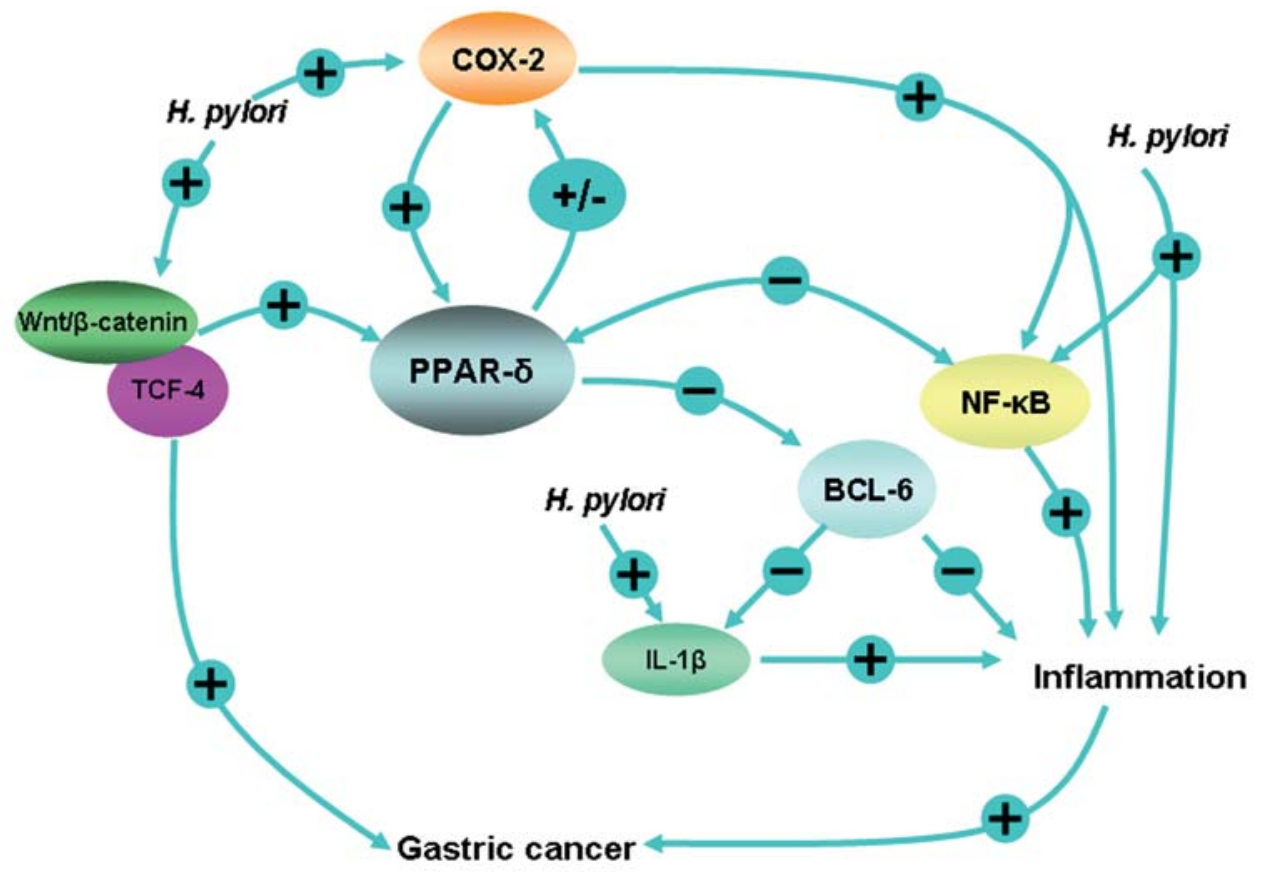

Figure 1. Schematic diagram of how PPAR $\delta$ may potentially mediate gastric cancer. Gastric cancer can be induced by $H$. pylori through multiple molecular

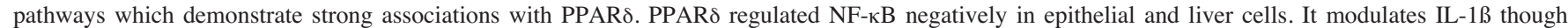
BCL-6, an inflammation suppressor protein which binds to PPAR $\delta$ receptor in the absence of ligand and releases from it upon ligand binding. Free BCL-6 suppresses the expression of multiple proinflammatory cytokines. PPAR $\delta$ activation was found to suppress COX-2 in lung cancer but induce COX-2 liver

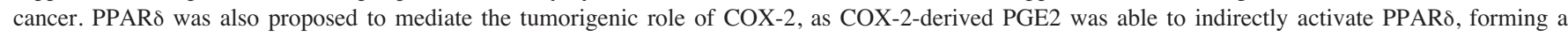
positive feed back mechanism which up-regulates COX-2. PPAR $\delta$ was shown to be a downstream target of Wnt- 3 -catenin/TCF-4 pathways, and its

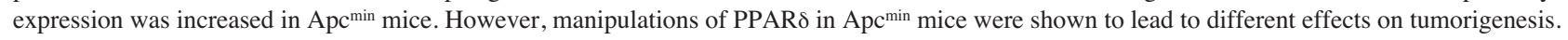

the ability to bind with chemicals that causes peroxisome proliferation, thus coined the term peroxisome proliferatoractivated receptor in the early 1990s. Subsequent studies identified PPAR $\gamma$ and PPAR $\delta$. Among the three PPARs, PPAR $\alpha$ is most highly expressed in muscle and liver, PPAR $\gamma$ is predominately expressed in adipose tissue, and PPARS is abundantly expressed throughout the body but only at low levels in the liver (5). Being identified as molecular targets of lipid metabolism and tumorigenesis, PPAR $\alpha$ and PPAR $\gamma$ have gained a major focus in the past decade and their physiological functions have been widely studied $(6,7)$. The study of PPAR $\delta$ has relatively lagged behind and the physiological role of PPAR $\delta$ is less understood compared with the other two PPAR isoforms.

\section{PPAR $\delta$ and its ligands}

PPARd plays an indispensable role in various physiological processes. Knockout of PPAR $\delta$ in mice has demonstrated multiple defects such as embryonic lethality, myelination defects, heart failure, decreased fat mass, and impaired skin inflammatory and wound healing response (8-11). PPARS can increase high-density lipoprotein (HDL) cholesterol and lower triglyceride level by modulating lipoprotein metabolism. Increased PPAR $\delta$ activity in the liver has been shown to suppress glucose output and contributes to insulin sensitizing (12). In skeletal muscle, PPAR $\delta$ regulates the formation of slow-twitch muscle fibers, fatty acid metabolism and transport (13). In cardiac muscle, PPAR $\delta$ maintains the basal fatty acid oxidation for normal cardiac mechanics (11).
PPARS also modulates inflammation through multiple mechanisms, one of which involves B cell lymphoma-6 (BCL-6), an inflammation suppressor protein which binds to PPAR $\delta$ receptor in the absence of ligand and releases from it upon ligand binding (14). Free BCL-6 suppresses the expression of multiple proinflammatory cytokines and chemokines $(15,16)$. PPAR $\delta$, but not PPAR $\alpha$ and PPAR $\gamma$, exhibits BCL- 6 binding ability (14).

Several naturally occurring eicosanoids such as prostaglandin A1, iolprost, and $15 \mathrm{~d}-\mathrm{J} 2$ are capable of activating PPARS (17-20). Fatty acids derived from very low-density lipoprotein enhance the expression of PPARS and are suggested to act as endogenous ligands (21). Although currently there is no PPAR $\delta$ agonist approved for clinical use, several synthetic agonists developed by combinational chemistry and structure-based drug design were shown to have high affinities for PPARS (22). Among them, GW501516 has been the most widely used selective agonist in demonstrating the physiological role of PPARd in both in vitro and in vivo studies.

\section{Roles of PPAR in tumorigenesis}

PPARS is involved in the control of cell proliferation, cell differentiation, and apoptosis, which is why its role in cancer development sparks both interests and debates (Table I). It has been shown that agonist-induced activation of PPARס causes growth inhibition in several solid tumor types including skin and lung (23-25), possibly through the inhibition of cell proliferation (26). PPAR $\delta$ activation has been shown to potentiate 
Table I. A comparison of roles of PPARס in cancer.

\begin{tabular}{|c|c|c|c|c|}
\hline $\begin{array}{l}\text { Type of } \\
\text { cancer }\end{array}$ & $\begin{array}{l}\text { Experiment } \\
\text { model }\end{array}$ & $\begin{array}{l}\text { Role in cancer } \\
\text { formation }\end{array}$ & Main phenotypic character & Refs. \\
\hline Skin & Mouse & - & $\begin{array}{l}\text { PPAR } \delta \text { null mice demonstrated earlier onset, enhanced size and } \\
\text { growth of tumor compared with wild-type in response to } \\
\text { chemically induced skin cancer }\end{array}$ & (23) \\
\hline Lung & Cell line & - & $\begin{array}{l}\text { L165041 mediated prostaglandin I2-induced cell apoptosis in human } \\
\text { lung cancer cell line A549 }\end{array}$ & (24) \\
\hline \multirow[t]{2}{*}{ Breast } & Mouse & + & $\begin{array}{l}\text { PPAR } \delta \text { agonist GW7845 accelerated tumor formation and resulted } \\
\text { in predominantly squamous cell carcinomas }\end{array}$ & (27) \\
\hline & Cell line & + & $\begin{array}{l}\text { PPAR } \delta \text { agonist stimulated cell proliferation in human breast cancer } \\
\text { cell lines T47D and MCF7 }\end{array}$ & (28) \\
\hline Prostate & Cell line & + & $\begin{array}{l}\text { PPARS agonist stimulated cell proliferation in human prostate cancer } \\
\text { cell lines LNCaP and PNT1A }\end{array}$ & (28) \\
\hline \multirow[t]{2}{*}{ Liver } & Cell line & + & $\begin{array}{l}\text { PPAR } \delta \text { agonist accelerated cell proliferation by a feed forward } \\
\text { mechanism through inducing COX-2 expression and } \mathrm{COX}-2 \text { derived } \\
\text { PGE }_{2} \text { in human hepatocellular carcinoma cell line } \mathrm{HuH} 7 \\
\text { HepG2 and Hep3B }\end{array}$ & $(29,30)$ \\
\hline & Mouse & - & $\begin{array}{l}\text { Chemically induced liver toxicity led to increased serum alanine } \\
\text { aminotransferase level, bile duct hyperplasia, regenerative hyperplasia } \\
\text { observed in PPARס null mice. but not in wild-type mice }\end{array}$ & $(50)$ \\
\hline \multirow[t]{4}{*}{$\begin{array}{l}\text { Small } \\
\text { intestine }\end{array}$} & Mouse & $=$ & 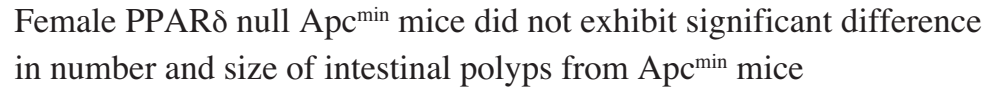 & (10) \\
\hline & Mouse & - & $\begin{array}{l}\text { PPARס null Apc }{ }^{\text {min }} \text { mice developed significantly larger tumors than } \\
\mathrm{Apc}^{\mathrm{min}} \text { mice regardless of sex }\end{array}$ & (71) \\
\hline & Mouse & - & $\begin{array}{l}\text { Female PPAR } \delta \text { null } \mathrm{Apc}^{\mathrm{min}} \text { mice developed more intestinal polyps } \\
\text { than } \mathrm{Apc}^{\mathrm{min}} \text { mice }\end{array}$ & (25) \\
\hline & Mouse & + & $\begin{array}{l}\text { PPAR } \delta \text { agonist GW501516 induced both polyp size and growth } \\
\text { in } \mathrm{Apc}^{\mathrm{min}} \text { mice }\end{array}$ & $(31)$ \\
\hline \multirow[t]{6}{*}{ Colon } & Cell line & - & $\begin{array}{l}\text { When inoculated as xenografts in nude mouse, PPAR } \delta \text { null human } \\
\text { colon cancer cell HCT } 116 \text { was less able to form tumor than } \\
\text { wild-type HCT116 cells }\end{array}$ & (33) \\
\hline & Cell line & - & 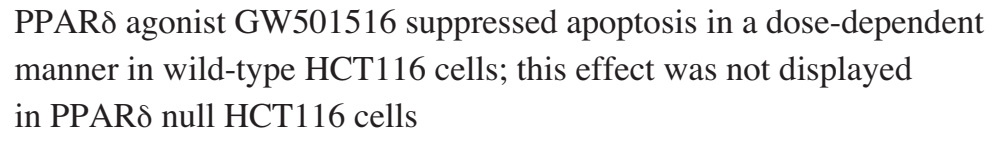 & $(31)$ \\
\hline & Mouse & - & $\begin{array}{l}\text { Female PPAR } \delta \text { null } A p c^{\text {min }} \text { mice developed significantly greater } \\
\text { number of polyps than } \mathrm{Apc}^{\text {min }} \text { mice }\end{array}$ & (71) \\
\hline & Mouse & $=$ & $\begin{array}{l}\text { PPAR } \delta \text { agonist GW501516 did not significantly induce polyp growth } \\
\text { in } \mathrm{Apc}^{\mathrm{min}} \text { mice }\end{array}$ & $(31)$ \\
\hline & Mouse & - & $\begin{array}{l}\text { PPAR null Apc }{ }^{\text {min }} \text { mice developed } 6 \text { times more polyps than did } \\
\mathrm{Apc}^{\mathrm{min}} \text { mice, regardless of sex }\end{array}$ & $(25)$ \\
\hline & Mouse & - & $\begin{array}{l}\text { Azoxymethane was able to induce more colon polyps in PPARd null } \\
\text { mice than in wild-type mice }\end{array}$ & $(25)$ \\
\hline
\end{tabular}

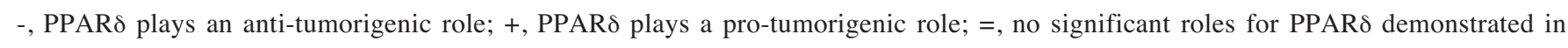
tumorigenesis.

the development of breast, prostate and liver cancers (27-30). There are conflicting data regarding the anti- or pro-tumorigenesis effects of PPAR $\delta$ in gastrointestinal cancers. Gupta et al reported that exposure of genetically engineered mice predisposed to intestinal polyposis $\left(\mathrm{Apc}^{\mathrm{min}}\right)$ to PPAR $\delta$ agonist significantly increased the number and size of intestinal polyps (31), whereas down-regulation of PPAR $\delta$ in colon cancer cells was able to induce apoptosis (32). Disruption of PPARס in human cancer cells was also able to decrease their ability to form tumors when inoculated as xenografts in nude mice 
(33). More recently, Shao et al reported PPARס as a target gene of oncogenic Ras protein, and K-Ras mediated transformation of intestinal epithelial cells had up-regulated PPARס (34). Opposite to these findings, in both the $\mathrm{Apc}^{\mathrm{min}}$ model and chemically induced model, colon polyp formation was found to be greater in size in mice nullizygous for PPAR $\delta$ (25). To date, there is no conclusive evidence on whether PPAR $\delta$ is anti- or pro-tumorigenic. Modulation of it was found to lead to different consequences in different types of cancer. Research on PPARd in gastrointestinal tumorigenesis has so far been mainly focused on small intestine and colon, and findings were rather contradictory.

\section{Background of gastric cancer}

Gastric cancer is the second leading cause of cancer-related death in the world $(1,2)$. The incidence of gastric cancer has been decreasing in the developed world over the past few decades but is still increasing in the developing world. Global new incidence is expected to reach 960,000 in 2010 and 1.1 million in 2020 with majority of cases occurring in developing countries. Risk factors for gastric cancer include Helicobacter pylori (H.pylori) infection, smoking and dietary factors such as insufficient fresh fruit and vegetable consumption and high salt uptake. A family history of gastric cancer will also increase individual susceptibility to the disease (35). It is now a widely accepted view that $H$. pylori infection is the primary initiator of the inflammatory and morphologic alterations such as atrophic gastritis and gastrointestinal metaplasia $(36,37)$ mediated by COX-2 overexpression (38), up-regulation of cyclinD1 by the Wnt signaling pathway through interaction of mucin 1 with $\beta$-catenin (39) and transcription factor (e.g., NF-kB) activation (40), leading to cell proliferation, excessive angiogenesis, inhibition of apoptosis and formation of gastric tumors. Epidemiologically, proinflammatory genotypes of the IL- $1 \mathrm{~b}$ and COX-2 gene are associated with an increased risk of gastric cancer and its precursors. The effects are most likely mediated through the induction of hypochlorhydria and severe gastritis with the subsequent development of gastric atrophy $(41,42)$.

Although eradication of $H$. pylori appears to be an attractive approach in preventing cancer, the data so far are limited and there is no effective chemopreventive agent available. Therapeutics targeting COX-2 was found to be promising in reducing the risk of gastric cancer; but longterm use of non-steroidal anti-inflammatory drugs (NSAIDs), that inhibit both COX-1 and COX-2, or selective inhibitors for COX-2 could lead to peptic ulcer diseases (43) and increase the risk of cardiovascular disease $(44,45)$. The mechanism behind the beneficial effect of COX-2 inhibition and its sideeffects remain to be better defined. Peroxisome proliferatoractivated receptors (PPARs) appear to be promising targets as chemopreventive agents. Cancer formation is associated with dysregulation of cellular differentiation, proliferation and apoptosis. Modulating these processes through the PPA receptor (PPAR) is a recent approach to cancer chemoprevention and therapy. Despite the paucity of data on the direct relationships between the three PPARs and gastric cancer, PPARS demonstrates particularly strong association with multiples pathways leading to gastric cancers.

\section{Potential effects of PPAR $\delta$ in gastric cancer}

To date, there is only one study in literature trying to demonstrate the relationship between PPAR $\delta$ and gastric cancer (46). In this particular study, Yu et al showed that PPAR $\delta$ was highly expressed in both normal gastric and gastric cancer samples. Treating gastric cell line MKN45 that overexpressed COX-2 with the specific COX-2 inhibitor resulted in a time- and dose-dependent suppression of PPARS expression. In contrast, there was no suppression of PPARd in the MKN28 gastric cell line, which had lower COX-2 expression. This leads to uncertainty whether PPAR $\delta$ plays a role in the chemopreventive effect of COX-2 inhibitor on gastric cancer. In spite of the paucity of research concerning their direct relationship, various studies have identified factors through which PPAR $\delta$ may mediate effects on gastric cancer development. These factors include nuclear factor- $\mathrm{B}(\mathrm{NF}-\kappa \mathrm{B})$, interleukin-1ß (IL-1ß), cyclooxygenase-2 (COX-2) and the Wnt- 3 -catenin/TCF-4 pathways.

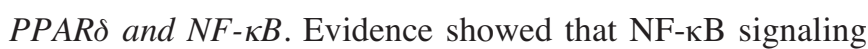
plays a pivotal role in inflammation-associated cancer. Activation of the NF- $\mathrm{KB}$ pathway by stimulation such as $H$. pylori infection begins with signal-induced phosphorylation of ІкB, an inhibitory protein that binds to NF- $\mathrm{KB}$ in the cytoplasm. This releases $\mathrm{NF}-\kappa \mathrm{B}$ and allows it to translocate into the nucleus where they activate transcription of proinflammatory genes $(47,48)$. Matsumoto et al showed that up-regulation of activation-induced cytidine deaminase (AID), a downstream target gene of NF- $\mathrm{KB}$, has led to the accumulation of nucleotide alterations in the TP53 tumor suppressor gene in gastric cells, which mediate the $H$. pylori infection-induced chronic gastric inflammation (48). Previous studies have demonstrated that PPAR $\delta$ agonist inhibited cytokine-induced nuclear trans-

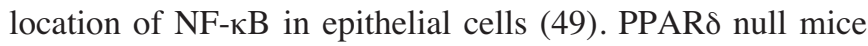
showed enhanced NF- $\mathrm{KB}$ expression in liver, and were more susceptible to chemically induced hepatoxicity (50). On the other hand, NF- $\kappa \mathrm{B}$ activation down-regulated PPAR $\delta$ activity during cardiac hypertrophy, possibly through protein-protein

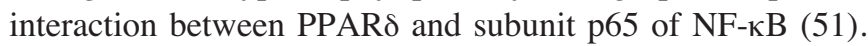

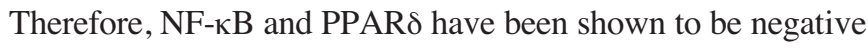
regulators of each other. PPAR $\delta$ activity may suppress NF$\kappa \mathrm{B}$-mediated inflammation; however, this modulation is yet to be validated in the development of gastric cancer.

PPARS and $I L-1 \beta$. Another key factor involved in the inflammatory response to $H$. pylori infection is the proinflammatory cytokine IL-1ß. Individuals with specific IL- $1 \beta$ genotypes that give raise to a higher IL-1ß synthetic level were found to have higher risk of developing gastric cancer upon $H$. pylori infection (52). Zeng et al studied IL-1ß gene polymorphisms and their association with gastric cancer in the Chinese population, and found that in low prevalence areas, IL-1ß-511T/T genotype is more common in gastric cancer patients than in normal subject. In high-prevalence areas, both control subjects and gastric cancer patients had high prevalence of proinflammatory genotype of IL-1ß$511 \mathrm{~T} / \mathrm{T}$ (53). IL-1ß was proposed to be a critical target of

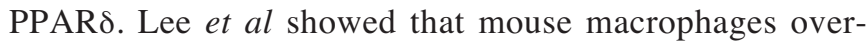

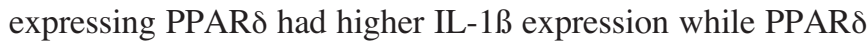


knockout macrophages had reduced IL-1ß expression. Interestingly, treatment with PPAR $\delta$ agonist (GW501516) reduced IL-1ß expression in wild-type and PPAR $\delta$ overexpressed macrophages (14). Thus the activation of IL-1B is PPAR $\delta$ receptor-dependent while the suppression of IL-1ß is PPARd ligand-dependent. This could probably be mediated through the inflammation repressor BCL-6 or direct gene targets of PPAR $\delta$ which have suppressive effects on IL-1ß expression $(14,22)$. However, further study is required to investigate the roles of direct target genes of PPARd. In addition, BCL-6 was found to suppress the expression of group IIA secretory phospholipase A2 (sPLA2-IIA), an enzyme that mediates the inflammatory response of IL-1ß, through transcriptional repression by promoter binding (16).

PPARS and COX-2. COX-2, a key enzyme in arachidonic acid biosynthesis, has been reported to be up-regulated in gastrointestinal cancers; and its overexpression is generally regarded to facilitate tumor development. Long-term use of COX-2 inhibitors has already been applied in the prevention of colorectal polyps in patients with familial adenomatous polyposis (FAP), an autosomal dominant disease caused by inactivation of adenomatous polyposis coli (APC) gene, and was shown to result in reduced risk for colorectal cancer (CRC) by $50 \%$ (54). In gastric cancer, COX-2 has been implicated in multiple tumorigenic processes including antiapoptosis (55), angiogenesis (56) and invasiveness (57). A population-based study showed that genetic polymorphism of COX-2 gene promoter region -1195A resulting in increased COX-2 expression was associated with 2-fold elevated risk of gastric cancer (42). COX-2 inhibitors were shown to suppress the development of gastric cancer $(46,58)$. Various studies have demonstrated the relationship between PPAR $\delta$ and COX-2 in different types of cancers. For example, PPAR $\delta$ activation induced by agonist L165041 down-regulated COX-2 expression in lung cancer (24). In liver cancer, by contrast, PPAR $\delta$ activation induced by agonist GW501516 was found to induce COX-2 expression in liver cancer and hepatocellular carcinoma (HCC) cell lines, while inhibition of PPAR $\delta$ by small interfering RNA suppressed growth of these cell lines $(29,30)$. The induction COX-2 derived prostaglandin $\mathrm{E}_{2}\left(\mathrm{PGE}_{2}\right)$ further activates PPARd, resulting in a feed forward loop (30). However, Hollingshead et al also demonstrated that PPAR agonists GW0742 and GW501516 were unable to modulate COX-2 in human colon and liver cell lines (59). Wang et al proposed a mediating role of PPARS in COX-2 tumorigenesis (60). They showed that treatment of COX-2 derived $\mathrm{PGE}_{2}$ promote intestinal epithelial cell survival and colorectal adenoma growth in $\mathrm{Apc}^{\text {min }}$ but not PPARS knockout Apc ${ }^{\text {min }}$ mice. Similarly, $\mathrm{PGE}_{2}$ decreased apoptosis of CRC cells but not cells expressing dominant negative PPAR protein, suggesting the induction of polyp growth by COX-2 was dependent on PPAR (60). This idea is consistent with the feed forward mechanism proposed by $\mathrm{Xu}$ et al (30). Yu et al has demonstrated the suppression of PPARd by COX-2 inhibitor in high COX-2 expressing gastric cancer cell line (46); however, it is not known whether the ameliorating effect of COX-2 inhibitor on the development of gastric cancer is mediated via PPAR $\delta$. The modulation of COX-2 by PPAR $\delta$ was shown to exhibit tissue specificity. Whether PPARS modulates COX-2 in gastric cancer remains to be elucidated. But there is growing evidence that PPAR $\delta$ mediates COX-2-initiated tumorigenesis through a feed forward mechanism. It would be interesting to consider interrupting PPAR $\delta$ as an alternative chemopreventive measure for gastric cancer besides COX-2 inhibitors.

PPARS and Wnt- $\beta$-catenin/TCF-4 pathway. The Wnt- $\beta$ catenin/TCF-4 pathway has been widely implicated in gastric cancer. The role of Wnt-ß-catenin/TCF-4 pathway was first discovered in the developmental process and was later found to be involved in tumorigenesis including the development of various gastrointestinal cancers. The association was identified in FAP, in which the inherited mutated APC was found to cause the development of adenomatous polyps in colon $(61,62)$. Subsequent studies found that APC contributes to the degradation of B-catenin, a protein which was able to bind with the transcription factor $\mathrm{T}$ cell factor 4 (TCF-4) and significantly enhanced transcription of its target genes including oncogenic c-myc, cyclin D1 and transcription factor PPARS (63-65). The accumulation of B-catenin in nucleus has been observed in $17-54 \%$ of gastric adenocarcinomas. FAP patients were found to have increased risk of gastric cancer (66-69). We and others have found functionally null mutations in APC and functionally activating mutations in B-catenin in gastric cancer (66-69). Treatment of N-methylnitrosourea (MNU) resulted in a more rapid gastric tumor development in $\mathrm{Apc}^{\mathrm{min}}$ than in wild-type mice (70). The promoter region of PPAR $\delta$ contains Tcf-4responsive elements. Thus, increased expression of APC protein could down-regulate PPAR expression through suppressing the B-catenin/TCF-4 pathway in colon cancer cell line (63). Gupta et al showed that giving PPAR $\delta$ agonist GW501516 to Apc ${ }^{\text {min }}$ mice caused development of larger polyps in the intestine compared to that of untreated mice. Pretreatment with GW501516 suppressed apoptosis in wildtype human CRC HCT116, but not in PPAR $\delta$ knockout HCT116 cells, suggesting the antiapoptotic effect is a result of PPARS activation (31). However, in a study adopting a genetic approach, knockout of PPARd was shown to increase the predisposition of $\mathrm{Apc}^{\mathrm{min}}$ mice to colon and intestinal tumorigenesis $(25,71)$. Such conflicting findings could possibly be a result of the functional difference between nonactivated PPAR $\delta$ receptor and ligand-bound activated PPAR $\delta$ receptor, a scenario described in the case with IL-1ß. Research on PPARS in APC mutant induced colon cancer has sparked as much debate as interest, although this pathway has also been found to increase susceptibility to gastric cancer, little is known about how PPAR $\delta$ would modulate gastric cancer induced APC mutation.

\section{Conclusions}

Although the direct relationship between PPAR $\delta$ and gastric cancer is less described, evidence suggests they are linked by pathways including NF-кB, IL- $1 \beta, \mathrm{COX}-2$ and Wnt-Bcatenin/TCF-4, the relationship is desribed in Fig. 1. PPAR $\delta$ was shown to regulate $\mathrm{NF}-\kappa \mathrm{B}$ negatively; whether its activation can suppress $\mathrm{NF}-\kappa \mathrm{B}$ mediated gastric inflammation 
deserves further validation. As in IL- $1 \beta$ signaling and Wnt- $\beta$ catenin/TCF-4 pathways, PPAR $\delta$ has demonstrated functional difference between its non-activated receptor and ligandbound activated receptor. It is worthwhile to investigate and distinguish the differences between the effects of PPAR $\delta$ overexpression by gene delivery and PPAR $\delta$ activation by ligands, along with attention to similar features occuring in gastric epithelial cells. Regulation of COX-2 by PPAR $\delta$ remains controversial since PPAR $\delta$ agonists can lead to different ways of COX-2 modulation in different cancers. PPAR $\delta$ was also shown to be an important factor in mediating COX-2 tumorigenesis. Clinically, this implies that a higher endogenous PPAR $\delta$ receptor level may lead to greater susceptibility to COX-2 mediated gastric cancer. There is also evidence demonstrating that the effect of NSAID or COX-2 inhibitor were at least partially mediated through inhibiting PPARס $(46,60,63)$, suggesting modulating PPARS could be a potential chemopreventive for reducing risk of gastric cancer. The argument over the tumorigenetic role of PPAR $\delta$ needs to be clarified. Future studies should try to identify genes that PPAR $\delta$ regulates in leading to particular anti- or pro-tumorigenetic effect. Distinguishing tissue specificity and the functional difference between non-activated receptor and activated receptor will help to understand the role of PPAR $\delta$ in different scenarios. The development of gastric cancer employs multiple pathways. Through identifying associations between PPAR $\delta$ and each of these pathways, this review provides the most updated evidence on how PPAR $\delta$ may impact on the development of gastric cancer. Unquestionably, the role of PPARS in gastric tumorigenesis will be better understood if future research effort could focus on demonstrating the direct relationship between them.

\section{References}

1. Crew KD and Neugut AI: Epidemiology of gastric cancer. World J Gastroenterol 12: 354-362, 2006.

2. Parkin DM, Bray F, Ferlay J and Pisani P: Global cancer statistics, 2002. CA Cancer J Clin 55: 74-108, 2005.

3. Lochhead P and El-Omar EM: Gastric cancer. Br Med Bull (In press).

4. Desvergne B and Wahli W: Peroxisome proliferator-activated receptors: nuclear control of metabolism. Endocr Rev 20: 649-688, 1999.

5. Evans RM, Barish GD and Wang YX: PPARs and the complex journey to obesity. Nat Med 10: 355-361, 2004.

6. Issemann I and Green S: Activation of a member of the steroid hormone receptor superfamily by peroxisome proliferators. Nature 347: 645-650, 1990.

7. Forman BM, Tontonoz P, Chen J, Brun RP, Spiegelman BM and Evans RM: 15-Deoxy-delta 12, 14-prostaglandin J2 is a ligand for the adipocyte determination factor PPAR gamma. Cell 83: 803-812, 1995 .

8. Tan GD, Fielding BA, Currie JM, et al: The effects of rosiglitazone on fatty acid and triglyceride metabolism in type 2 diabetes. Diabetologia 48: 83-95, 2005.

9. Peters JM, Lee SS, Li W, et al: Growth, adipose, brain, and skin alterations resulting from targeted disruption of the mouse peroxisome proliferator-activated receptor beta(delta). Mol Cell Biol 20: 5119-5128, 2000.

10. Barak Y, Liao D, He W, et al: Effects of peroxisome proliferatoractivated receptor delta on placentation, adiposity and colorectal cancer. Proc Natl Acad Sci USA 99: 303-308, 2002.

11. Cheng L, Ding G, Qin Q, et al: Cardiomyocyte-restricted peroxisome proliferator-activated receptor-delta deletion perturbs myocardial fatty acid oxidation and leads to cardiomyopathy. Nat Med 10: 1245-1250, 2004.
12. Lee $\mathrm{CH}$, Olson $\mathrm{P}$, Hevener $\mathrm{A}$, et al: PPARdelta regulates glucose metabolism and insulin sensitivity. Proc Natl Acad Sci USA 103: 3444-3449, 2006.

13. Wang YX, Zhang CL, Yu RT, et al: Regulation of muscle fiber type and running endurance by PPARdelta. PLoS Biol 2: E294, 2004.

14. Lee $\mathrm{CH}$, Chawla A, Urbiztondo $\mathrm{N}$, et al: Transcriptional repression of atherogenic inflammation: modulation by PPARdelta. Science 302: 453-457, 2003.

15. Toney LM, Cattoretti G, Graf JA, et al: BCL-6 regulates chemokine gene transcription in macrophages. Nat Immunol 1: 214-220, 2000.

16. Ravaux L, Denoyelle C, Monne C, Limon I, Raymondjean M and El Hadri K: Inhibition of interleukin-1beta-induced group IIA secretory phospholipase A2 expression by peroxisome proliferator-activated receptors (PPARs) in rat vascular smooth muscle cells: cooperation between PPARbeta and the protooncogene BCL-6. Mol Cell Biol 27: 8374-8387, 2007.

17. Xu HE, Lambert MH, Montana VG, et al: Molecular recognition of fatty acids by peroxisome proliferator-activated receptors. Mol Cell 3: 397-403, 1999.

18. Forman BM, Chen J and Evans RM: Hypolipidemic drugs, polyunsaturated fatty acids and eicosanoids are ligands for peroxisome proliferator-activated receptors alpha and delta. Proc Natl Acad Sci USA 94: 4312-4317, 1997.

19. Yu K, Bayona W, Kallen CB, et al: Differential activation of peroxisome proliferator-activated receptors by eicosanoids. J Biol Chem 270: 23975-23983, 1995.

20. Krey G, Braissant O, L'Horset F, et al: Fatty acids, eicosanoids and hypolipidemic agents identified as ligands of peroxisome proliferator-activated receptors by coactivator-dependent receptor ligand assay. Mol Endocrinol 11: 779-791, 1997.

21. Chawla A, Lee CH, Barak Y, et al: PPARdelta is a very lowdensity lipoprotein sensor in macrophages. Proc Natl Acad Sci USA 100: 1268-1273, 2003.

22. Barish GD, Narkar VA and Evans RM: PPAR delta: a dagger in the heart of the metabolic syndrome. J Clin Invest 116: 590-597, 2006.

23. Kim DJ, Akiyama TE, Harman FS, et al: Peroxisome proliferator-activated receptor beta (delta)-dependent regulation of ubiquitin $C$ expression contributes to attenuation of skin carcinogenesis. J Biol Chem 279: 23719-23727, 2004.

24. Fukumoto K, Yano Y, Virgona N, et al: Peroxisome proliferatoractivated receptor delta as a molecular target to regulate lung cancer cell growth. FEBS Lett 579: 3829-3836, 2005.

25. Harman FS, Nicol CJ, Marin HE, Ward JM, Gonzalez FJ and Peters JM: Peroxisome proliferator-activated receptor-delta attenuates colon carcinogenesis. Nat Med 10: 481-483, 2004.

26. Kim DJ, Murray IA, Burns AM, Gonzalez FJ, Perdew GH and Peters JM: Peroxisome proliferator-activated receptor-beta/delta inhibits epidermal cell proliferation by down-regulation of kinase activity. J Biol Chem 280: 9519-9527, 2005.

27. Yin Y, Russell RG, Dettin LE, et al: Peroxisome proliferatoractivated receptor delta and gamma agonists differentially alter tumor differentiation and progression during mammary carcinogenesis. Cancer Res 65: 3950-3957, 2005.

28. Stephen RL, Gustafsson MC, Jarvis M, et al: Activation of peroxisome proliferator-activated receptor delta stimulates the proliferation of human breast and prostate cancer cell lines. Cancer Res 64: 3162-3170, 2004.

29. Glinghammar B, Skogsberg J, Hamsten A and Ehrenborg E: PPARdelta activation induces COX-2 gene expression and cell proliferation in human hepatocellular carcinoma cells. Biochem Biophys Res Commun 308: 361-368, 2003.

30. Xu L, Han C, Lim K and Wu T: Cross-talk between peroxisome proliferator-activated receptor delta and cytosolic phospholipase $\mathrm{A}(2)$ alpha/cyclooxygenase-2/prostaglandin $\mathrm{E}(2)$ signaling pathways in human hepatocellular carcinoma cells. Cancer Res 66: 11859-11868, 2006.

31. Gupta RA, Wang D, Katkuri S, Wang H, Dey SK and DuBois RN: Activation of nuclear hormone receptor peroxisome proliferatoractivated receptor-delta accelerates intestinal adenoma growth. Nat Med 10: 245-247, 2004.

32. Shureiqi I, Jiang W, Zuo X, et al: The 15-lipoxygenase-1 product 13-S-hydroxyoctadecadienoic acid down-regulates PPAR-delta to induce apoptosis in colorectal cancer cells. Proc Natl Acad Sci USA 100: 9968-9973, 2003.

33. Park BH, Vogelstein B and Kinzler KW: Genetic disruption of PPARdelta decreases the tumorigenicity of human colon cancer cells. Proc Natl Acad Sci USA 98: 2598-2603, 2001. 
34. Shao J, Sheng H and DuBois RN: Peroxisome proliferatoractivated receptors modulate K-Ras-mediated transformation of intestinal epithelial cells. Cancer Res 62: 3282-3288, 2002.

35. Forman D and Burley VJ: Gastric cancer: global pattern of the disease and an overview of environmental risk factors. Best Pract Res Clin Gastroenterol 20: 633-649, 2006.

36. Eslick GD: Helicobacter pylori infection causes gastric cancer? A review of the epidemiological, meta-analytic and experimental evidence. World J Gastroenterol 12: 2991-2999, 2006.

37. Prinz C, Schwendy S and Voland P: H. pylori and gastric cancer: shifting the global burden. World J Gastroenterol 12: 5458-5464, 2006.

38. Konturek PC, Konturek SJ and Brzozowski T: Gastric cancer and Helicobacter pylori infection. J Physiol Pharmacol 57 (Suppl. 3): S51-S65, 2006.

39. Udhayakumar G, Jayanthi V, Devaraj N and Devaraj H: Interaction of MUC1 with beta-catenin modulates the Wnt target gene cyclinD1 in $H$. pylori-induced gastric cancer. Mol Carcinog 46: 807-817, 2007

40. Hatakeyama M and Brzozowski T: Pathogenesis of Helicobacter pylori infection. Helicobacter 11 (Suppl. 1): S14-S20, 2006.

41. Permin $\mathrm{H}$ and Andersen LP: Inflammation, immunity, and vaccines for Helicobacter infection. Helicobacter 10 (Suppl. 1): S21-S25, 2005

42. Liu F, Pan K, Zhang X, et al: Genetic variants in cyclooxygenase-2: Expression and risk of gastric cancer and its precursors in a Chinese population. Gastroenterology 130 1975-1984, 2006.

43. Langman MJ, Weil J, Wainwright $\mathrm{P}$, et al: Risks of bleeding peptic ulcer associated with individual non-steroidal antiinflammatory drugs. Lancet 343: 1075-1078, 1994.

44. Solomon SD, McMurray JJ, Pfeffer MA, et al: Cardiovascular risk associated with celecoxib in a clinical trial for colorectal adenoma prevention. N Engl J Med 352: 1071-1080, 2005.

45. Bresalier RS, Sandler RS, Quan H, et al: Cardiovascular events associated with rofecoxib in a colorectal adenoma chemoprevention trial. N Engl J Med 352: 1092-1102, 2005.

46. Yu J, Leung WK, Chen J, Ebert MP, Malfertheiner P and Sung JJ: Expression of peroxisome proliferator-activated receptor delta in human gastric cancer and its response to specific COX-2 inhibitor. Cancer Lett 223: 11-17, 2005.

47. Verma IM and Stevenson J: IkappaB kinase: beginning, not the end. Proc Natl Acad Sci USA 94: 11758-11760, 1997.

48. Matsumoto Y, Marusawa H, Kinoshita K, et al: Helicobacter pylori infection triggers aberrant expression of activationinduced cytidine deaminase in gastric epithelium. Nat Med 13: 470-476, 2007.

49. Rival Y, Beneteau N, Taillandier T, et al: PPARalpha and PPARdelta activators inhibit cytokine-induced nuclear translocation of NF-kappaB and expression of VCAM-1 in EAhy926 endothelial cells. Eur J Pharmacol 435: 143-151, 2002.

50. Shan W, Nicol CJ, Ito S, et al: Peroxisome proliferator-activated receptor-beta/delta protects against chemically induced liver toxicity in mice. Hepatology 47: 225-235, 2008.

51. Planavila A, Rodriguez-Calvo R, Jove M, et al: Peroxisome proliferator-activated receptor beta/delta activation inhibits hypertrophy in neonatal rat cardiomyocytes. Cardiovasc Res 65 : 832-841, 2005.

52. Hwang IR, Kodama T, Kikuchi S, et al: Effect of interleukin 1 polymorphisms on gastric mucosal interleukin 1beta production in Helicobacter pylori infection. Gastroenterology 123: 1793$1803,2002$.
53. Zeng ZR, Hu PJ, Hu S, et al: Association of interleukin 1B gene polymorphism and gastric cancers in high and low prevalence regions in China. Gut 52: 1684-1689, 2003.

54. Steinbach G, Lynch PM, Phillips RK, et al: The effect of celecoxib, a cyclooxygenase- 2 inhibitor, in familial adenomatous polyposis. N Engl J Med 342: 1946-1952, 2000.

55. Tatsuguchi A, Matsui K, Shinji Y, et al: Cyclooxygenase-2 expression correlates with angiogenesis and apoptosis in gastric cancer tissue. Hum Pathol 35: 488-495, 2004.

56. Leung WK, To KF, Go MY, et al: Cyclooxygenase-2 upregulates vascular endothelial growth factor expression and angiogenesis in human gastric carcinoma. Int J Oncol 23: 1317-1322, 2003

57. Murata H, Kawano S, Tsuji S, et al: Cyclooxygenase-2 overexpression enhances lymphatic invasion and metastasis in human gastric carcinoma. Am J Gastroenterol 94: 451-455, 1999.

58. Hu PJ, Yu J, Zeng ZR, et al: Chemoprevention of gastric cancer by celecoxib in rats. Gut 53: 195-200, 2004

59. Hollingshead HE, Killins RL, Borland MG, et al: Peroxisome proliferator-activated receptor-beta/delta (PPARbeta/delta) ligands do not potentiate growth of human cancer cell lines. Carcinogenesis 28: 2641-2649, 2007.

60. Wang D, Wang H, Shi Q, et al: Prostaglandin $\mathrm{E}(2)$ promotes colorectal adenoma growth via transactivation of the nuclear peroxisome proliferator-activated receptor delta. Cancer Cell 6: 285-295, 2004

61. Kinzler KW, Nilbert MC, Vogelstein B, et al: Identification of a gene located at chromosome $5 \mathrm{q} 21$ that is mutated in colorectal cancers. Science 251: 1366-1370, 1991.

62. Nishisho I, Nakamura Y, Miyoshi Y, et al: Mutations of chromosome 5q21 genes in FAP and colorectal cancer patients. Science 253: 665-669, 1991

63. He TC, Chan TA, Vogelstein B and Kinzler KW: PPARdelta is an APC-regulated target of non-steroidal anti-inflammatory drugs. Cell 99: 335-345, 1999.

64. He TC, Sparks AB, Rago C, et al: Identification of c-MYC as a target of the APC pathway. Science 281: 1509-1512, 1998.

65. Tetsu $\mathrm{O}$ and McCormick F: Beta-catenin regulates expression of cyclin D1 in colon carcinoma cells. Nature 398: 422-426, 1999.

66. Horii A, Nakatsuru S, Miyoshi Y, et al: The APC gene, responsible for familial adenomatous polyposis, is mutated in human gastric cancer. Cancer Res 52: 3231-3233, 1992.

67. Ebert MP, Fei G, Kahmann S, et al: Increased beta-catenin mRNA levels and mutational alterations of the APC and betacatenin gene are present in intestinal-type gastric cancer. Carcinogenesis 23: 87-91, 2002.

68. Lee JH, Abraham SC, Kim HS, et al: Inverse relationship between APC gene mutation in gastric adenomas and development of adenocarcinoma. Am J Pathol 161: 611-618, 2002.

69. Ushijima T and Sasako M: Focus on gastric cancer. Cancer Cell 5: $121-125,2004$.

70. Tomita H, Yamada Y, Oyama T, et al: Development of gastric tumors in $\mathrm{Apc}(\mathrm{Min} /+)$ mice by the activation of the betacatenin/Tcf signaling pathway. Cancer Res 67: 4079-4087, 2007.

71. Reed KR, Sansom OJ, Hayes AJ, et al: PPARdelta status and Apc-mediated tumourigenesis in the mouse intestine. Oncogene 23: 8992-8996, 2004 